\title{
Financial Liquidity, Asset Management and Financial Performance in Indonesia Listed Companies
}

\author{
Mohammad Arief
}

Faculty of Economics and Business, Department of Management, University of Trunojoyo Madura, Indonesia

Email: papi.arief@gmail.com

\begin{abstract}
This study aims to examine the effect of liquidity, asset management, cash turnover and capital structure on financial performance in manufacturing companies listed on the Indonesia Stock Exchange. The research was conducted with a quantitative research approach. This type of research is descriptive research. The population in the study as many as 159 companies and the number of samples of 85 manufacturing companies are listed on the Stock Exchange Indonesia. The variables related to this research are liquidity (current ratio), asset management (total asset turnover), cash turnover, capital structure (debt to equity ratio) and Return on Asset. The research method used is the classical assumption test method and multiple linear regression analysis. The results showed that partially liquidity (current ratio) had a significant effect on Return on Asset, Asset Management (total asset turnover) had a significant effect on Return on Asset, and Cash Turnover (debt to equity ratio) had no significant effect. Return on Asset and Capital Structure have no significant effect on Return on Asset (ROA). Simultaneously Liquidity (current ratio), Asset Management (total asset turnover), Turnover Cash (cash turnover) and Capital Structure (debt to equity ratio) affect significantly to the Financial Performance in Indonesia Listed Companies.
\end{abstract}

Keywords - Liquidity; Management of Asset; Cash Turnover; Capital Structure; Financial Performance.

\section{Introduction}

The economic development of every company in the current era of globalization is very dynamic. Wherein each company has a main purpose especially, obtaining profit. And to maintain this profit, an examination of its financial health is required. The way to see financial health is seen from its financial ratios. Where in practice there are five financial ratios, namely the Liquidity Ratio, Solvency Ratio, Activity Ratio, Market Value Ratio, and Profitability Race.

So from the five financial ratios, the researcher uses the liquidity ratio to measure the company's ability to overcome short-term debt, namely the analysis used is the Current Ratio and cash turnover. The solvency ratio is used to determine the extent to which the company's assets are financed with debt, which is measured using the Debt to Equity Ratio and the activity ratio used is TATO (Total Assets Turnover). So that researchers can use the four ratios to measure how much it affects financial performance, namely ROA (Return On Assets), especially in manufacturing companies listed on the Indonesia Stock Exchange.

Table 1. Research Phenomena

\begin{tabular}{|l|l|l|l|l|l|l|}
\hline Issuers Code & Year & Current Assets & Total Assets & \multicolumn{1}{|c|}{ Sales } & Total Equity & $\begin{array}{c}\text { Income After } \\
\text { Tax }\end{array}$ \\
\hline \multirow{4}{*}{ AKPI } & 2016 & 870.146 .141 .000 & 2.615 .909 .190 .000 & 2.047 .218 .639 .000 & 1.120 .035 .169 .000 & 52.393 .857 .000 \\
\cline { 2 - 8 } & 2017 & 1.003 .030 .428 .000 & 2.745 .325 .853 .000 & 2.064 .857 .643 .000 & 1.126 .612 .491 .000 & 13.333 .970 .000 \\
\cline { 2 - 8 } & 2018 & 1.233 .718 .090 .000 & 3.070 .410 .492 .000 & 2.387 .420 .036 .000 & 1.233 .853 .753 .000 & 64.226 .271 .000 \\
\hline \multirow{3}{*}{ TALF } & 2016 & 325.494 .162 .443 & 881.673 .021 .959 & 569.419 .992 .907 & 751.895 .484 .850 & 30.137 .707 .324 \\
\cline { 2 - 8 } & 2017 & 351.255 .636 .607 & 921.240 .988 .517 & 646.087 .885 .410 & 766.164 .851 .785 & 21.465 .856 .784 \\
\cline { 2 - 8 } & 2018 & 405.988 .723 .901 & 984.597 .771 .989 & 741.055 .147 .778 & 808.378 .986 .806 & 43.976 .734 .000 \\
\hline
\end{tabular}

Source: Indonesia Stock Exchange Data

Based on table 1 above shows 2 examples of manufacturing companies, the phenomenon that occurs in the company PT. Argha Karya Prima Ind. (AKPI) Tbk from 2017 to 2018 experienced an increase in current assets of IDR. 230,687,662,000.Meanwhile, net profit after tax has increased from IDR. 13,333,970,000 in 2017 to
IDR. 64,226,271,000 in 2018. This company also experienced an increase in sales from 2016 to 2017 amounting to IDR. 17,639,004,000, while the net profit after tax has decreased from IDR. 52,393,857,000 in 2016 to IDR. 13.33397 billion in the year 2017.In the company PT. Tunas Alfin (TALF) Tbk from 2016 to 2017 
experienced an increase in total assets of IDR. 39,567,966,558. Meanwhile, net profit after tax decreased from IDR. 30,137,707,324 in 2016 and IDR. $21,465,856,784$ in 2017. This company also experienced an increase in total equity in 2017 to 2018 amounting to IDR. $42,214,155,023$, while the net profit after tax has increased from IDR. $21,465,856,784$ in 2017 to IDR. 43,976,734,000 in 2018.

\section{Literature Review}

\subsection{Liquidity}

According to (Fahmi, 2017), the liquidity ratio is the potential for a company to meet its short-term obligations in a timely manner. According to (Hery, 2015), argues that the ratio to measure liquidity is the current ratio. Current ratio is used to measure a company's potential to meet its short-term obligations (debt) which are due soon by using total current assets. The indicator formula used for looking for the current ratio is as follows:

$$
\text { Current Ratio }=\frac{\text { Current Assets }}{\text { Current Liabilities }}
$$

\subsection{Asset Management}

Asset management is the structured process of costeffective level, operating, maintaining, upgrading, and disposing of assets. This term is most often used in the world of finance to describe objects and companies that manage investments on behalf of others.

According to (Brigham \& Houston, 2010), found the ratio to measure asset management is the total assets turnover ratio. A total asset turnover ratio is a ratio used to measure the turnover of all company assets and is calculated by dividing sales by total assets. The indicator formula used to find the total asset turnover ratio is as follows:

$$
\text { TotalAssetsTurnover }=\frac{\text { Sales }}{\text { Total Assets }}
$$

\subsection{Cash Turnover}

According to (Nuriyani \& Zannati, 2017), cash turnover is a period starting at the time of turning cash where cash was invested in working capital liquidity highest level in order to achieve a high sales volume as well. According to (Nurafika \& Almadany, 2018), the formula whichused to find the cash turnover ratio is as follows:

$$
\text { Cash Turnover }=\frac{\text { Sales }}{\text { Average Cash }}
$$

$$
\text { Average Cash }=\frac{\text { Cash Beginning }+ \text { Cash End }}{2}
$$

\subsection{Capital Structure}

According to (Fahmi, 2017), Capital Structure is a description of the form of the company's financial scale, namely the capital it owns sourced from long-term debt (long-term liabilities) and own capital (shareholders ' equity) is a financial source for a company.

According to (Hery, 2015), argues that the ratio to measure capital structure is the Debt to Equity Ratio. Debt to Equity Ratio is a ratio used to measure the proportion of debt to equity. The indicator formula used to find the Debt to Equity Ratio is as follows:

$$
\text { DebttoEquityRatio }=\frac{\text { Total Debt }}{\text { Total Capital }}
$$

\subsection{Financial Performance}

According to (Fahmi, 2017), financial performance is a description and research conducted to see to what extent a company has implemented it by using proper and precise financial implementation rules.

According to (Hery, 2017), argues that the ratio for measuring financial performance is Return on Assets. Return on Assets is a ratio that shows the results (return) on the use of company assets in creating net income. According to (Nurafika \& Almadany, 2018), the formula of the indicators used to men looking for returnon assets are as follows:

$$
\text { Return On Asset }=\frac{\text { Net Profit After Tax }}{\text { Total Assets }} \times 100 \%
$$

\section{Research Frame work}

\subsection{The Effect of Liquidity on Financial Performance}

The ratio used in liquidity is Current Ratio. According to (Subramanyam \& Wild, 2014), the current ratio demonstrated its ability to me filled the current liabilities. If the increasingly high number of current assets to current liabilities, the greater the confidence that obligation well will be paid, then the dynamically affect financial performance.

\subsection{The Effect of Asset Management on Financial Performance}

The ratio used in asset management is the ratio of total asset turnover. According to (Hery, 2017), total assets turnover show how the effectiveness of the company's total 
assets in generating sales so it is able to improve the performance of the financial fine.

\subsection{Effect of Cash Turnover on Financial Performance}

According to (Widiasmoro, 2017), cash turnover shows the ability of cash to generate income, so it can affect the company's overall financial performance.

\subsection{The Effect of Capital Structure on Financial Performance}

The ratio used in the capital structure is the Debt to Equity Ratio. According to (Lestari \& Goddess, 2016), the value of debt- to -equity ratio, which is low indicates a company's Return on Asset (ROA) are good because the higher the company's ability to pay its obligations.

Research Framework - To find out the relationship between the independent variable (x) and the dependent variable (y) used in this study, it can be seen in Figure 1 below:

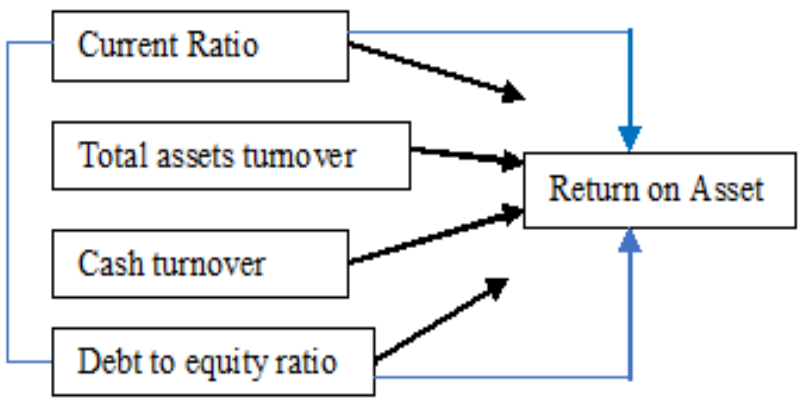

Fig.1: Research framework

\subsection{Research Hypothesis}

Based on the conceptual framework of the hypothesis above, the hypothesis proposed in this study is as follows:

H1: Liquidity (CR) has a significant effect on Return on Asset (ROA) in manufacturing companies listed on the Indonesia Stock Exchange.
H2: Asset Management (TATO) has a significant effect on Return on Asset (ROA) in manufacturing companies listed on the Indonesia Stock Exchange.

H3: Cash Turnover has a significant effect on Return on Asset (ROA) in manufacturing companies listed on the Indonesia Stock Exchange.

H4: Capital Structure (DER) has a significant effect on Return on Asset (ROA) in manufacturing companies listed on the Indonesia Stock Exchange.

H5: Liquidity (CR), Asset Management (TATO), Cash Turnover and Capital Structure (DER) simultaneously have a significant effect on Return on Asset (ROA) in manufacturing companies listed on the Indonesia Stock Exchange.

\section{Research Methods}

\subsection{Research Approach}

In this research approach, researchers used quantitative research methods. According to (Sugiyono, 2011), quantitative research can be defined as a research method based on the philosophy of positivism, used for researching specific populations or samples, sampling techniques are generally carried out randomly, data collection using research instruments, quantitative / statistical data analys is with the aim of testing predetermined hypotheses. The philosophy of positivism views that phenomenon as concrete, observable and measurable. Variable dependent in this study is liquidity proxies with Current Ratio, Asset Management proxied by Total Assets Turnover Ratio, Cash Turnover, and Capital Structure which is proxied by the Debt to Equity Ratio.

\subsection{Population and Sample}

According to (Sugiyono, 2011), population is a generalization area consisting of objects / subjects that have certain qualities and characteristics that are determined by researchers to be studied and then draw conclusions. The population in this study are manufacturing companies listed on the Indonesia Stock Exchange, amounting to 159 companies in 2016-2018

Table 2. Research Sample

\begin{tabular}{|c|l|c|}
\hline No. & Criteria & Number \\
\hline 1. & Manufacturing company listed on the Indonesia Stock Exchange & 159 \\
\hline 2. & $\begin{array}{l}\text { Manufacturing companies that do not publish their financial } \\
\text { reports regularly during the 2016-2018 period }\end{array}$ & 42 \\
\hline 3. & $\begin{array}{l}\text { Manufacturing companies that incur losses in the period } \\
2016-2018\end{array}$ & 43 \\
\hline \multicolumn{2}{|l|}{ Number of Research Samples } & 85 \\
\hline \multicolumn{2}{|l|}{ Total Sample (company 85 x 3 years) } \\
\hline
\end{tabular}

Source: www.idx.co.id (data processed) 


\subsection{Classic Assumption Test}

Normality Test - The normality test aims to determine whether in the regression model, the confounding variable or residual. The normality test is used to test whether the data is normally distributed or not.

Table 3. Normality Test

\begin{tabular}{|c|c|c|}
\hline One-Sample Kolr & ogorov-Smi & $\begin{array}{l}\text { ov Test } \\
\text { Unstandardiz } \\
\text { ed Residual }\end{array}$ \\
\hline $\mathrm{N}$ & & 180 \\
\hline \multirow[t]{2}{*}{ Normal Parameters ${ }^{a \cdot b}$} & Mean & .0000000 \\
\hline & Std. Deviation & .07965311 \\
\hline \multirow[t]{3}{*}{ Most Extreme Differences } & Absolute & .042 \\
\hline & Positive & .034 \\
\hline & Negative & -.042 \\
\hline Kolmogorov-Smirnov Z & & .568 \\
\hline Asymp. Sig. (2-tailed) & & .903 \\
\hline
\end{tabular}

\subsection{Statistical Analysis}

Based on the results of the Kolmogorov Smirnov Test in table 3.1 above, it shows that the variables CR (X 1), TATO (X 2), CT (X 3), DER (X 4) andROA (Y) can be said to benormally distributed. This can be seen from the results of the Kolmogorov Smirnov test showing the Asymp value. Sig.(2-tailed) $0.903>0.05$.

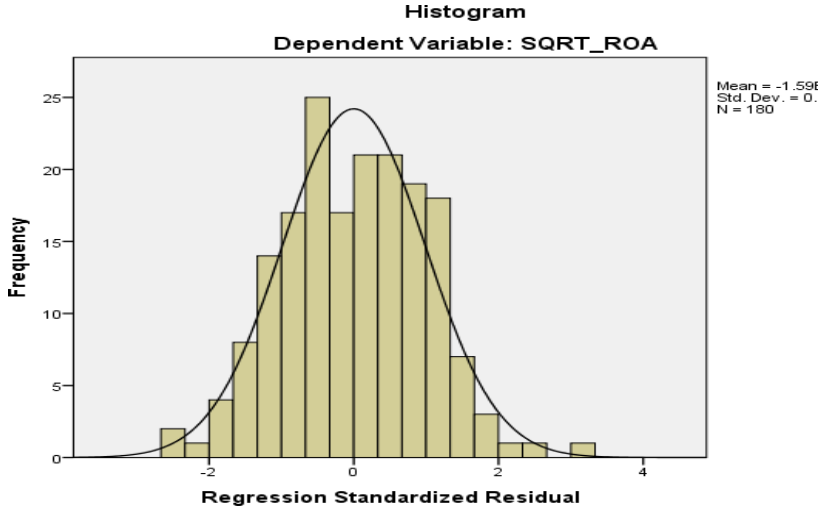

Fig. 2: Normality Test - Histogram
Based on the graphic display histogram in Figure 2 above shows the curve line in the middle and not dominant to the right or to the left so that it can be said that the residuals generated distributed throughout the normal way.

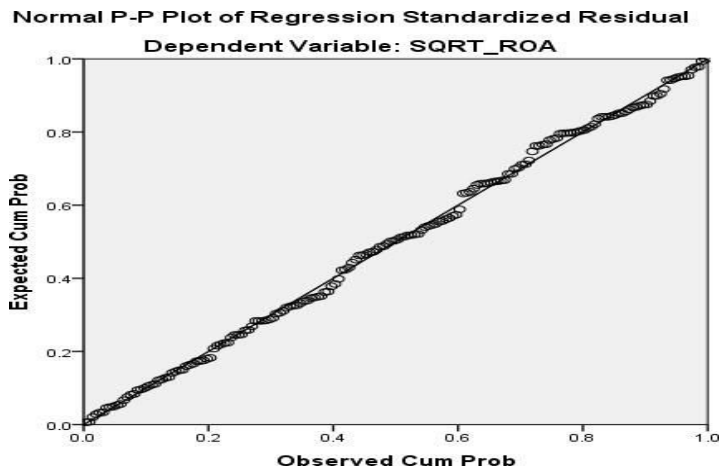

Fig.3: Normality Test -Probability Plot

Based on graphic display normality probability plot in the figure 3 can be seen that the points follow the diagonal line so that it can be concluded that the data is normally distributed.

Multicollinearity Test - The multicollinearity test aims to test whether the regression model finds a correlation between the independent variables. Multicollinearity testing is done by looking at the VIF between the independent variables.

Based on table below shows that the tolerance value for the CR variable is $0.542>0.10$, the tolerance value for the TATO variable is $0.944>0.10$, the tolerance value for the CT variable was $0.769>0.10$, and the tolerance value for the DER variable was $0.609>0.10$. And the VIF value of the CR variable is $1.845<10.00$, the VIF value of the TATO variable is $1.059<10.00$, the VIF value of the CT variable $1.301<10.00$, and the VIF value of the DER variable $1.641<10.00$. This can indicate that the tolerance value > from 0.10 and the VIF value <than 10.00, then from this result there is no multicollinearity and it can be concluded that there is no correlation between the independent variables.

Table 4. Multicollinearity Test

\begin{tabular}{|c|c|c|c|c|c|c|c|c|c|c|c|c|}
\hline \multirow[b]{2}{*}{ Model } & \multicolumn{2}{|c|}{$\begin{array}{l}\text { Unstandardized } \\
\text { Coefficients }\end{array}$} & \multirow{2}{*}{$\begin{array}{c}\begin{array}{c}\text { Stand } \\
\text { ardize } \\
d \\
\text { Coeffi } \\
\text { cients }\end{array} \\
\text { Beta }\end{array}$} & \multirow[b]{2}{*}{$\mathrm{t}$} & \multirow[b]{2}{*}{ Sig. } & $\begin{array}{r}95 \\
\text { Conf } \\
\text { Interv }\end{array}$ & $\begin{array}{l}0 \% \\
\text { dence } \\
\text { al for B }\end{array}$ & \multicolumn{3}{|c|}{ Correlations } & \multicolumn{2}{|c|}{$\begin{array}{l}\text { Collinearity St } \\
\text { atistics }\end{array}$} \\
\hline & $\mathrm{B}$ & $\begin{array}{l}\text { Std. } \\
\text { Error }\end{array}$ & & & & $\begin{array}{l}\text { Lower } \\
\text { Bound }\end{array}$ & $\begin{array}{l}\text { Upper } \\
\text { Bound }\end{array}$ & $\begin{array}{l}\text { Zero- } \\
\text { order }\end{array}$ & Partial & Part & $\begin{array}{c}\text { Tolera } \\
\text { nce }\end{array}$ & VIF \\
\hline 1 (Constant) & .027 & .053 & & .512 & .609 & -.077 & .131 & & & & & \\
\hline SQRT_CR & .078 & .020 & .344 & 3.797 & .000 & .037 & .118 & .387 & .276 & .254 & .542 & 1.845 \\
\hline SQRT_TATO & .110 & .028 & .271 & 3.941 & .000 & .055 & .165 & .269 & .285 & .263 & .944 & 1.059 \\
\hline SQRT_CT & -.003 & .003 & -.057 & -.747 & .456 & -.010 & .004 & -.165 & -.056 & -.050 & .769 & 1.301 \\
\hline SQRT_DER & -.005 & .026 & -.016 & -.189 & .850 & -.056 & .046 & -.228 & -.014 & -.013 & .609 & 1.641 \\
\hline
\end{tabular}




\subsection{Heteroscedasticity Test}

The regression test can be said to be good if there is no heteroscedasticity problem, in this study the researcher took the method by using a chart diagram (scatter plot). With the premise of: 1). If there is a specific pattern such as dots that form a particular pattern of regular (wavy, widened, then narrowed), it can be classified heteroscedasticity. 2). If there is no clear pattern, as well as the points spread above and below then it does not happen the problem of heteroscedasticity.

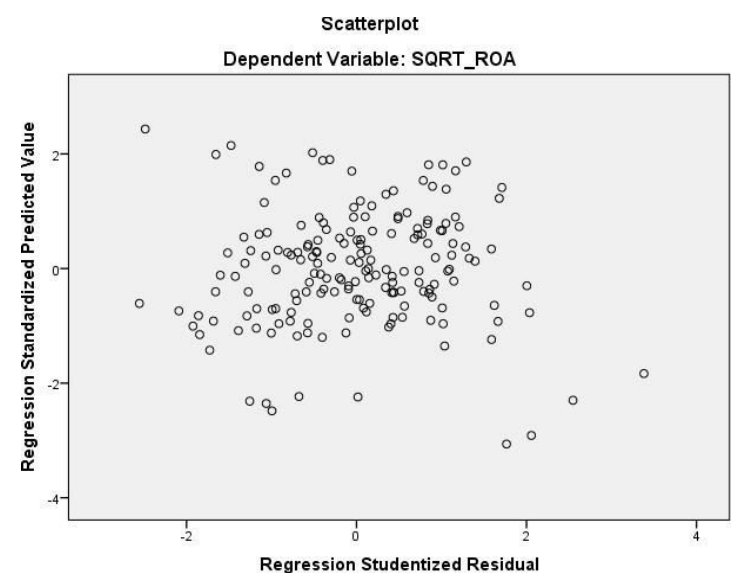

Fig. 4: Heteroscedasticity Test $S$ catterplot

Based on the display in the figure 4 above, it can be seen that the dots are spread randomly no upward or downward. Thus it can be concluded that there is no heteroscedasticity problem.

Autocorrelation Test - Test autocorrelation aims to test whether the linear regression model was no correlation between errors intruder in period $t$ with bullies errors in the periods $\mathrm{t}-1$ (previous). In this research test used is the Model Summary, where if $\mathrm{d}<\mathrm{dl}$ or $\mathrm{d}>4$-dl then there is autocorrelation, then if $\mathrm{du}<\mathrm{d}<4-\mathrm{du}$ there is no autocorrelation and if $\mathrm{dl}<\mathrm{d}<\mathrm{du}$ or $4-\mathrm{du}<\mathrm{d}<4-\mathrm{dl}$ then there is no conclusion.

From the statistical results in table 5 above, it can be seen that $\mathrm{dl}<\mathrm{d}<\mathrm{du}$, namely $1.7109<1.773<1.8017$, it can be concluded that there is no autocorrelation.

\subsection{Multiple Linear Regression Analysis Test}

Multiple linear regression analysis is used to find the relationship or influence between the independent variables (Current Ratio, Total Asset Turnover, Cash Turnover, and Debt to Equity Ratio) on the dependent variable (Return on Asset). According to (Sanusi, 2011), multiple linear regression is basically an extension of simple linear regression, namely increasing the number independent variables previously only became two or more independent variables. In this study, there are four independent variables (independent) and one dependent variable (dependent). Thus, multiple linear regressions can be formulated by:

$$
Y=a+b 1 X 1+b 2 X 2+b 3 X 3+b 4 X 4+e
$$

\section{Results and Discussion}

\subsection{Partial t-test}

The statistical test basically shows how far the influence of one explanatory / independent variable individually in explaining the variation of the dependent variable. The null hypothesis $(\mathrm{H} 0)$ to be tested is whether a parameter (bi) is equal to zero.

Table 5. Partial test result

\begin{tabular}{|c|c|c|c|c|c|}
\hline \multirow[b]{2}{*}{ Model } & \multicolumn{2}{|c|}{$\begin{array}{l}\text { Unstandardized } \\
\text { Coefficients }\end{array}$} & \multirow{2}{*}{$\begin{array}{c}\begin{array}{c}\text { Standa } \\
\text { rdized } \\
\text { Coef } \mathrm{fi} \\
\text { cients }\end{array} \\
\text { Beta }\end{array}$} & \multirow[b]{2}{*}{$\mathrm{t}$} & \multirow[b]{2}{*}{ Sig. } \\
\hline & B & $\begin{array}{l}\text { Std. } \\
\text { Error }\end{array}$ & & & \\
\hline $\begin{array}{ll}1 & \text { (Constant) } \\
& \text { SQRT_CR }\end{array}$ & $\begin{array}{l}.027 \\
.078\end{array}$ & $\begin{array}{l}.053 \\
.020\end{array}$ & .344 & $\begin{array}{r}.512 \\
3.797\end{array}$ & $\begin{array}{l}.609 \\
.000\end{array}$ \\
\hline SQRT_TATO & .110 & .028 & .271 & 3.941 & .000 \\
\hline SQRT_CT & -.003 & .003 & -.057 & -.747 & .456 \\
\hline SQRT_DER & -.005 & .026 & -.016 & -.189 & .850 \\
\hline
\end{tabular}

From table 5 above shows $0.000<0.05$, these results indicate that $\mathrm{CR}$ is significant to ROA. Other results can also be seen from the $\mathrm{t}$ count of 3,797> from the $\mathrm{t}$-table, namely amounting to $1,974 . \mathrm{t}$ table is obtained by the formula ( $\alpha / 2$; nk-1), namely $0.025 ; 174$ and the results of the tm table show 1.974. This indicates accepting the stated alternative hypothesis that an independent variable individually affects the independent variable.

TATO test can also be seen from $0,000<$ from 0.05 , this shows that TATO is significant for ROA. Meanwhile $t$ arithmetic amounted to $3.941>$ of t table 1.974 suggesting accept the alternative hypothesis TATO. Furthermore, testing of CT can also be seen from $0.456>$ from 0.05 , this shows that CT is not significant for ROA. Meanwhile $t$ arithmetic of $-0.747<$ of $\mathrm{t}$ table 1.974 showed reject this alternative hypothesis CT, and for testing the DER shows $0.850>0.05$, this result shows that DER is not significant to ROA. And also this shows that rejecting the alternative hypothesis can be seen that $\mathrm{t}$ count is -0.189 <from $\mathrm{t}$ table 1.974.

\subsection{F-Test}

The F-test is used to show whether all the independent variables included in the model have a joint influence on the dependent variable. 


\section{Table 6. F-Test Result}

\begin{tabular}{|c|c|c|c|c|c|c|}
\hline \multicolumn{7}{|c|}{ ANOVA $^{a}$} \\
\hline \multicolumn{2}{|c|}{ Model } & $\begin{array}{l}\text { Sum of } \\
\text { Squares }\end{array}$ & df & Mean Square & F & Sig. \\
\hline \multirow[t]{3}{*}{1} & Regression & 319 & 4 & .080 & 12.291 & $.000^{b}$ \\
\hline & Residual & 1.136 & 175 & .006 & & \\
\hline & Total & 1.455 & 179 & & & \\
\hline
\end{tabular}

From the results of statistical testing in table 6, it can be seen that the significant value is 0.000 and less than 0.05 , and the result of $\mathrm{F}$ count shows a value of 12.291 which is greater than the $\mathrm{F}$ table of 2.42 . F table in the can of the results of the calculation of $F(k ; n k)=F(4 ; 176)$ and after being seen from the $\mathrm{F}$ table it shows that the result is 2.42. From the results of the statistical test, the independent variables CR (X1), TATO (X2), CT (X3) and DER (X4) affect the dependent variable ROA (Y).

The Effect of Current Ratio to the Return On Asset From the partial test results, it can be seen that the results of statistical testing through SPSS show that the TATO test is seen from the Sig value in the Coefficients table, namely $0.000<0.05$, these results indicate that $\mathrm{CR}$ is significant on ROA. Other results can also be seen from the $t$ count of $3,797>$ from the $t$ table which is equal to 1.974 . The $t$ table is obtained by the formula ( $\alpha / 2 ; n k-1)$, namely $0.025 ; 174$ and the $t$ table results show 1.974. This indicates accepting the alternative hypothesis which states that an independent variable individually affects the independent variable.

The Effect of Total Asset Turnover Of Return On Assets - From the partial test results, it can be seen that the results of statistical testing through SPSS show that the TATO test is seen from the Sig value in the Coefficients table is $0.000<$ from 0.05 , this indicates that TATO is significant towards ROA. While the $\mathrm{t}$ arithmetic amounted to $3.941>$ from $t$ table 1.974 , this indicates accepting the alternative hypothes is of TATO.

The Effect of Cash Turnover Of Return On Assets From the partial test results, it can be seen that the results of statistical testing through SPSS show that the CT test is seen from the Sig value in the Coefficients table, namely 0.456> Of 0.05 , regard this indicates that the CT is not significant to ROA. Meanwhile $t$ count se large $-0.747<\mathrm{t}$ table 1.974 showed reject this alternative hypothesis CT.

The Effect of Debt to Equity Ratio Of Return On Assets - From the partial test results, it can be seen that the results of statistical testing through SPSS show that the DER test shows the Sig value on the Coefficients table, namely $0.850>0.05$, this result shows that DER is not significant to ROA. And also it shows the men megrim alternative hypothesis can be seen that $\mathrm{t}$ arithmetic of 0.189 <of t table 1.974 .

\section{Conclusion}

From the results of this study the following conclusions were obtained:

- Liquidity (Current Ratio) partially positive and significant impact on Return on Asset (ROA) in manufacturing companies that listed on the Indonesia Stock Exchange, so the first hypothesis (H1) in this study is accepted.

- Asset Management (Total Assets Turnover) partially has a positive and significant effect on Return on Asset (ROA) in manufacturing companies listed on the Indonesia Stock Exchange, so that the second hypothesis (H2) in this study is accepted.

- Turnover Cash (Cash Turnover) partially and no significant negative effect on the Return on Asset (ROA) in manufacturing companies listed in Indonesia Stock Exchange, making it the third hypothesis (H3) in this study ditola $\mathrm{k}$.

- Capital Structure (Debt to Equity Ratio) partially has a negative and insignificant effect on Return on Asset (ROA) in manufacturing companies listed on the Indonesia Stock Exchange, so the fourth hypothesis (H4) in this study is rejected.

- Current Ratio, Total Asset Turnover, Cash Turnover and Debt to Equity Ratio simultaneously significant effect on Return on Asset (ROA) in manufacturing companies listed in Indonesia Stock Exchange, so hypothesis fifth (H5) in this study received.

\subsection{Suggestion}

The suggestions put forward by the researcher regarding the research results are:

- For manufacturing companies, management should pay attention to Current Ratio and Total Assets Turn over because these variables can affect Return on Asset (ROA).

- For further research, it is advisable to download handicraft study variables net income or size of the company because the coefficient of determination showed $78.1 \%$ of the variation of the dependent variable (ROA) might be explained by variables outside the research.

\section{References}

[1] Burksaitiene, D., Draugele, L. (2018), Capital structure impact on liquidity management. International Journal of Economics, Business and Management Research, 2(1), 110-127.

[2] Cheriyan, N.K., Daniel, L. (2019), Relationship between Liquidity, Volatility and Trading Activity: An Intraday Analysis of Indian 
Stock Market. International Journal of Economics and Financial Issues, 9(1), 17-22.

[3] Demirgunes, K. (2016), The effect of liquidity on financial performance: Evidencefrom Turkish retail industry. International Journal of Economics and Finance, 8(4), 63-79.

[4] Endah, W., Nurlaela, S., Titisari, K.H. (2017), The effect of liquidity ratio, productivity ratio, profitability ratio, and solvability ratio on sukuk ranking. Accounting and Tax Journal, 18(1), 130-139.

[5] Ghasemi, M., Ab-Razak, N.H. (2016), The impact of liquidity on the capital structure: Evidence from Malaysia. International Journal of Economics and Finance, 8(10), 130-139.

[6] Liaqat, I., Saddique, S., Bagh, T., Khan, M.A., Naseer, M.M., Khan, M.A. (2017), Capital structure as driving force of financial performance: Case of energy and fuel sector of Pakistan. International Journal of Accounting and Financial Reporting, 7(1), 86-100.

[7] Marfuah, S.A., Nurlaela, S. (2017), Effect of company size, asset growth, profitability, and sales growth on the capital structure of the cosmetics and household company on the Indonesia stock ex change. Accounting and Tax Journal, 18(1), 16-30.

[8] Gladys, M., Omagwa, J. (2017), Asset structure and financial performance: A case of the Nairobi securities exchange, Kenya. Research Journal of Finance and Accounting, 8(4), 192-200.
[9] Nainggolan, H.L., Pratiwi, P.S. (2017), Analysis of factors affecting corporate financial performance. Media Economics and Management, 32(1), 80-96.

[10] Obilikwu, J. (2018), The imact of capital, concentration, size and liquidity on banking industry performance in Nigeria. International Journal of Economics and Financial Issues, 8(4), 54-60.

[11] Olusuyi, A.E., Felix, A.E. (2017), The effect of capital structure on the financial performance of manufacturing firms in Nigeria (20082014). Journal of Accounting and Financial Management, 3(3), 37 48

[12] Osaretin, K.O., Sodik, A.O., Fredrick, I. (2019), Capital structure and the profitability-liquidity trade-off. International Journal of Economics and Financial Issues, 9(3), 48-64.

[13] Vy, L.T.P., Nguyet, P.T.B. (2017), Capital structure and firm performance: Empirical evidence from a small transition country. Research in International Business and Finance, 42, 710-726.

[14] Yusuf, M., Surjaatmadja, S. (2018), Analysis of financial performance on profitability with non performance financing as variable moderation. International Journal of Economics and Financial Issues, 8(4), 126-132. 